\title{
ESTUDO AVALIATIVO DAS CLASSES DE ACELERAÇÃO NA REDE ESTADUAL PAULISTA
}

\author{
VERAMARIA NIGRO DE SOUZAPLACCO \\ Pontifícia Universidade Católica - SP \\ MARLIE. D. AFONSO DEANDRÉ \\ Universidade de São Paulo \\ LAURINDARAMALHO DEALMEIDA \\ Pontifícia Universidade Católica - SP
}

\section{RESUMO}

Este artigo descreve os propósitos, a metodologia e os resultados de um estudo avaliativo sobre a implantação do Projeto das Classes de Aceleração no Estado de São Paulo. A realização de seis estudos de caso, em escolas nas quais a implantação foi considerada bem-sucedida, permitiu identificar fatores de sucesso do projeto. A análise de provas de desempenho e de auto-estima de alunos egressos da classes de aceleração indicou a importância de incorporar ao projeto, medidas de médio e longo prazo que ajudem a manter os resultados positivos alcançados.

PROJETO DAS CLASSES DEACELERAÇÃO-SÃO PAULO-SUCESSO ESCOLAR-INCLUSÃO/EXCLUSATO DO ALUNO-DEFASAGEMIDADE-SÉRIE

\begin{abstract}
IMPLANTATION OF ACCELERATED CLASSES IN THE STATE PUBLIC SCHOOL NETWORK: AN EVALUATIVESTUDY. This article describes the proposals, methodology and results of an evaluative study on the implantation of the Project for Accelerated Classes in the State of São Paulo. Six case studies in schools where implantation was considered to have been successful, permitted the identification of the factors for success in the project. The analysis of performance tests and of the self esteem of student graduates of the accelerated (remedial) classes indicated the importance of incorporating evaluative measures over the long and medium term to help maintain the positive results achieved.
\end{abstract}




\section{APRESENTAÇÃO}

presente artigo descreve os objetivos, a metodologia e os resultados de uma investigação sobre o Projeto das Classes de Aceleração do Estado de São Paulo. A apresentação dos dados é feita em duas seções, seguindo a própria estrutura do estudo, que abrange duas vertentes: uma que explora os fatores de sucesso do projeto e a outra que analisa o desempenho escolar e o nível de auto-estima dos seus egressos.

A metodologia foi diferente nos dois estudos, em atendimento aos objetivos pretendidos, ou seja:

- Identificar, em escolas nas quais o projeto foi bem sucedido, os fatores desse sucesso e verificar em que medida os princípios norteadores do projeto, no que se refere às metodologias de ensino, avaliação, relação professor-aluno e organização do espaço pedagógico, foram incorporados pelos educadores que dele participaram;

- Verificar o impacto do projeto mediante a análise do desempenho dos alunos egressos das Classes de Aceleração, ora cursando as 4a s e 5a s séries, comparando-os com os demais alunos do ensino regular.

Para investigar os fatores relacionados ao sucesso das classes de aceleração, foi utilizada a metodologia do estudo de caso do tipo etnográfico, incluindo observações de aula e demais atividades escolares; entrevistas com professores, diretores, coordenadores pedagógicos, supervisores, dirigentes regionais e pais; registros fotográficos; análise de documentos escolares e de produções de alunos.

Para avaliar o impacto do projeto, foi realizado um estudo que incluiu a aplicação de provas de desempenho e de auto-estima em alunos egressos e não egressos, complementadas por dados de entrevistas realizadas com professores.

A pesquisa foi realizada por meio de convênio entre a Fundação para o Desenvolvimento da Educação - FDE - , órgão da Secretaria de Educação do Estado de São Paulo e o Programa de Estudos Pós-Graduados em Psicologia da Educação da PUC/SP.

\section{INTRODUÇÃO}

Segundo o documento "Reorganização da Trajetória Escolar no Ensino Fundamental: Classes de Aceleração. Proposta Pedagógica Curricular" (São Paulo, SEE/FDE, 1997), a implementação de classes de aceleração nas escolas da Rede Estadual de Ensino visa a eliminar a defasagem entre série e idade regular de matrícula, em alunos que freqüentam da $1^{\mathrm{a}}$ à $4^{\mathrm{a}}$ série do ensino fundamental, criando condições para que avancem no percurso escolar e passem a freqüentar uma série mais compatível com a sua idade. 
Assim, o projeto se propõe, ao resgatar a auto-estima de alunos que, após repetidas reprovações ou em decorrência da evasão escolar, se encontram em atraso em relação à escolaridade regular, possibilitar-Ihes oportunidades de aprendizagem e de desenvolvimento de habilidades necessárias à sua reintegração a essa escolaridade.

O Projeto Classes de Aceleração tem como princípios teórico-metodológicos:

- uma visão positiva das possibilidades dos alunos e

- uma aposta no crescimento da competência da escola.

Tendo como referência esses princípios, o trabalho a ser realizado em sala de aula deve desenvolver-se de maneira intencional e flexível, mobilizando o aluno à participação e ao pensamento criativo e possibilitando a melhoria de sua auto-estima e autoconfiança. Esse trabalho, portanto, deve ser dinâmico, centrado em interações construtivas entre professor e aluno e entre aluno e conhecimento, considerando-se ainda que o repertório de conhecimentos que os alunos já trazem é ponto de partida fundamental para o êxito do trabalho. $\bigcirc$ conhecimento, tratado como um bem socialmente acumulado e sistematizado, não deve ser objeto de mera transmissão, mas sim trabalhado em movimentos de elaboração, integração e interação na sala de aula e apropriado pelo aluno, nas múltiplas oportunidades oferecidas por esse ambiente. Nesse contexto, o desenvolvimento de conceitos e habilidades básicas é a síntese do trabalho integrado conteúdo-forma-interação.

Com esses pressupostos, a Secretaria da Educação do Estado - SEE/SP -, por intermédio da Fundação para o Desenvolvimento da Educação - FDE -, elaborou a proposta curricular para as classes de aceleração e, em fevereiro de 1996, implantou classes de aceleração em 160 escolas da Rede Estadual de Ensino. De início, elas envolveram 417 professores e 10.350 alunos com defasagem idade/série, isto é, alunos que ultrapassaram em dois anos ou mais a idade prevista para a série em que se encontravam matriculados. No ano de 1997, a proposta foi ampliada para 80 I escolas, atendendo a 40.870 alunos. Em 1998 , ।.716 escolas e 73.850 alunos foram atendidos pelo projeto.

A proposta, ao acolher alunos de ciclo básico à $4^{\mathrm{a}}$ série que se encontram defasados em relação à idade regular de matrícula, objetivou dar-lhes oportunidade de retomar, com sucesso, o percurso escolar estabelecido no sistema de ensino. A marca fundamental das classes de aceleração foi oferecer a essa clientela um ensino adequado, que não significa educação compensatória nem implica exigências mais baixas. Ao contrário, essas classes representaram a possibilidade de se contar com um ensino de conteúdo elevado, pleno de atividades estimulantes e de desafios significativos, capazes de provocar expectativas mais positivas de desempenho escolar em professores, alunos e pais.

Após três anos de sua implantação, o projeto pode ser considerado um sucesso. Testemunham esse fato inúmeros depoimentos de professores, alunos e suas respectivas famílias. 
Para que se pudesse ter uma visão mais ampla e, ao mesmo tempo, mais focada desses resultados, foi empreendida a investigação ora relatada. Assim, este artigo descreve os propósitos e as ações desencadeadas na avaliação externa, bem como dos resultados por ela revelados. $\bigcirc$ objetivo geral da pesquisa avaliativa foi verificar se os alunos egressos das classes de aceleração e reintegrados ao ensino regular apresentam desempenho compatível ao dos demais alunos, bem como identificar e analisar os fatores de sucesso das classes de aceleração.

De forma mais específica, buscou-se:

- identificar, em escolas nas quais o projeto foi bem-sucedido, os fatores associados a esse sucesso;

- verificar o impacto do projeto, pela análise do desempenho dos alunos egressos das classes de aceleração, ora cursando as $4^{a}$ e $5^{a}$ séries, comparando-o com o desempenho dos demais alunos do ensino regular.

Para a realização da pesquisa avaliativa, constituiu-se uma equipe de trabalho, composta, no princípio, por três pesquisadoras, sendo duas professoras da PUC/SP e uma professora da USP, autoras deste artigo. Assumindo a coordenação do trabalho, essa equipe definiu alguns critérios para constituição do grupo de pesquisadores colaboradores: experiência anterior de pesquisa em escola, conhecimento da rede pública de ensino e disponibilidade para envolver-se no trabalho, no espaço de tempo determinado.

Após uma reunião com um grupo de interessados, foram selecionados dez profissionais' com experiências e titulações diversas: duas professoras da PUC/SP, duas professoras da UNESP, dois recém-doutores pela USP, uma doutoranda-professora da PUC/SP, duas doutorandas-professoras da UNITAU e uma ex-coordenadora pedagógica da rede municipal de ensino.

A preparação da equipe para o início do trabalho envolveu:

- leitura e discussão do material fornecido pela FDE relativo ao projeto das classes de aceleração;

- conhecimento das outras pesquisas e projetos realizados nos Estados de São Paulo, Minas Gerais, Paraná e Maranhão que focalizavam as classes de aceleração;

- levantamento de referências bibliográficas para aplicação dos fundamentos teóricos do estudo e para embasamento na construção dos instrumentos de coleta de dados.

I. Além das coordenadoras Vera M. N. S. Placco, Marli André e Laurinda R. Almeida, a equipe foi composta por Helena Machado de Paula Albuquerque, Laurizete F. Passos, Maria Aparecida Campos Cruz Castro, Maria de Lourdes Bara Zanotto, Maria Teresa de Moura Ribeiro, Maristela Angotti, Monica Helena Tieppo Alves Gianfaldoni, Neuza Bertoni Pinto, Rita Maria M. L. Boaretto e Wagner Rodrigues Valente. 
Essa preparação inicial teve continuidade nas reuniões sistemáticas da equipe, propiciando o projeto, na realidade, a formação continuada dos pesquisadores, por meio de discussões teórico-metodológicas e de problemas encontrados no processo de coleta de dados.

Buscando atingir objetivos amplos, que possibilitassem aferir o impacto do projeto, tanto em termos de processo quanto de produto, o estudo utilizou metodologias diferentes, evidenciando, assim, resultados diferentes, o que justifica a sua apresentação em duas seções distintas.

\section{ESTUDOS DE CASO DOS FATORES DE SUCESSO}

Estudo ।

Por meio de estudos de caso, buscou-se identificar, em escolas nas quais o projeto foi muito bem-sucedido, os fatores desse sucesso, bem como o impacto do projeto sobre os sujeitos e as unidades escolares. Nessas escolas, foram aprofundadas as observações e análises relativas às alterações nos ambientes e nas relações entre os sujeitos das ações, em razão da implementação do Projeto Classes de Aceleração.

Os estudos de caso foram realizados em seis escolas, sendo duas na capital, uma na Grande São Paulo e três no interior do Estado de São Paulo.

Os critérios para seleção das escolas foram: terem reconhecido sucesso, por parte da comunidade escolar, na implantação das classes de aceleração e abrangerem diferentes regiões do estado.

A coleta de dados foi realizada por uma dupla de pesquisadores para possibilitar visão mais fidedigna e rica das situações investigadas. As visitas ocorreram durante os meses de setembro e outubro de 1998.

Os procedimentos de coleta de dados para constituição dos estudos de caso incluíram: visitas às salas de aula, visando a observar a organização do espaço, a rotina diária da sala de aula, a interação professor-aluno e o uso do material; elaboração de um diário de campo com anotações cursivas sobre o processo de aproximação à escola e dados de sua história e de seu contexto; registros fotográficos. Para complementar essas informações, foram coletados materiais produzidos pelos alunos e documentos escolares importantes. Além disso, foram feitas entrevistas com os agentes envolvidos no projeto: dirigentes regionais, supervisores de ensino, diretores, professores coordenadores, professores das classes de aceleração, alunos e pais.

No acesso às escolas não foram encontrados quaisquer impedimentos, seja por parte dos dirigentes regionais, seja por parte da direção das escolas. Ao contrário, os pesquisadores foram sempre muito bem recebidos e, em grande parte das visitas, foram gentilmente acompanhados pelos supervisores. Nas escolas, a receptividade ao trabalho foi ótima, o que facilitou sobremaneira a obtenção dos dados. 
Foram feitas em média seis visitas a cada escola, levando em conta as atividades da rotina escolar, a disponibilidade dos entrevistados, maior ou menor facilidade no acesso aos dados e a localização da escola.

Em uma das escolas a observação de aulas ficou prejudicada porque ocorreram várias atividades extra-classe no período da visita e como se localizava no interior do estado, não foi possível retornar mais vezes (ao todo foram realizadas sete visitas nesta escola). Tentou-se superar essa dificuldade recolhendo as produções dos alunos, que juntamente com os depoimentos dos entrevistados substituíram razoavelmente as observações.

Em outra escola, também do interior, o acesso aos dados foi extremamente facilitado pelo pessoal da escola, de modo que o período de visitas pôde ser abreviado.

Essas condições especiais que circunscreveram cada caso, imprimiram-lhes características também especiais. Essa variação torna-se evidente nos seis relatos dos casos. Respeitando ao mesmo tempo a variedade e o que é peculiar à metodologia de estudo de caso ênfase no singular, privilegiando a análise em profundidade, elaborou-se um relatório sobre cada escola.

Mas, também julgando importante e desejável identificar elementos similares nos diversos casos, fazemos aqui uma tentativa de síntese dos aspectos comuns a todos eles e procuramos apontar tendências que podem ser úteis para a revisão do projeto e para definição de políticas e metas futuras.

\section{Síntese dos resultados dos estudos de caso}

\section{Contexto escolar das classes de aceleração}

$\mathrm{Na}$ caracterização de cada escola focalizada ficou evidente que nenhuma delas possui traços ou condições excepcionais seja quanto ao aspecto físico, seja quanto aos recursos materiais, que por si só possam responder pelo trabalho diferenciado que vêm desenvolvendo com o projeto das classes de aceleração.

São escolas em condições normais de funcionamento, algumas com o prédio em estado um pouco mais precário do que outras, mas tendo, de forma geral, boas instalações tanto para o atendimento a alunos e professores quanto para o pessoal técnico-administrativo. Em duas escolas o cuidado com o jardim chamava a atenção. A grama estava aparada, as plantas arrumadas, o piso encerado e havia muitas flores "parecendo um cartão postal".

Ainda do ponto de vista da estrutura física, em todas elas a classe de aceleração ocupa um espaço diferenciado, de uso exclusivo dessas turmas, o que parece ser um fator bastante positivo, segundo a opinião dos entrevistados, porque permite aos professores desenvolver, junto aos alunos, atitudes em relação ao ambiente e ao material de classe, sem preocupação com sua conservação ou destruição por outras turmas. Diz a professora da escola L: "O importante é que ninguém ocupa a minha sala à tarde. Eu posso deixar o quadro cheio e retomar no dia seguinte". 
Outro ponto positivo é a localização das salas de aceleração entre as salas comuns de outras séries, evitando atitudes de discriminação. Na única escola em que as classes de aceleração estão isoladas do corpo principal do prédio, observamos por um lado maior resistência que nas demais, por parte de outros professores, para aceitação do projeto. Por outro lado percebemos que as professoras das classes de aceleração se sentiam um pouco isoladas e sem muita atenção da diretora da escola.

Quanto aos demais recursos materiais, como pátio, cantina, biblioteca, número de salas de aula e de carteiras e material de uso corrente, as escolas dispõem do essencial para o funcionamento normal sem qualquer traço que as diferencie das demais. Quanto aos recursos humanos também não foram encontradas condições excepcionais que as distingam, tendo o mínimo necessário para realização de um bom trabalho.

Do ponto de vista da organização do trabalho pedagógico, pôde-se perceber nessas escolas uma presença atuante da direção e da coordenadora pedagógica, e um claro comprometimento delas com o projeto. Isso ficou muito evidente nas nossas observações, nas entrevistas feitas e principalmente nos depoimentos colhidos junto aos pais e professores das classes de aceleração. Tanto a direção quanto a coordenação pedagógica parecem ter um papel fundamental no sucesso do projeto.

Alguns exemplos coletados nas observações:

- Na escola M, a diretora e a coordenadora visitam a classe de aceleração, conversam com os alunos e fazem comentários sobre seus trabalhos.

- Na escola C, a professora coordenadora faz observações constantes na classe de aceleração. Os alunos pedem o seu visto nos cadernos e às vezes levam-nos até a sala dela para mostrá-los.

- A diretora da escola A mostra um intenso trabalho com os pais e com a comunidade. Chama os pais dos alunos faltosos, realiza reuniões para dar-lhes orientações sobre o acompanhamento dos filhos e organiza atividades sociais para apresentar o trabalho da escola.

- Na escola J, as reuniões dos professores são realizadas no horário do almoço, para que todos possam participar. Há um período da reunião para os encontros por série, quando as professoras das classes de aceleração se reúnem com as de $2^{\mathrm{a}}$ e $4^{\mathrm{a}}$ séries.

Foram coletados vários depoimentos dos agentes escolares que testemunham sua crença no projeto e entusiasmo em relação aos resultados. A fala da coordenadora pedagógica da escola A é bem ilustrativa nesse sentido:

O que é importante na aceleração é a evolução do aluno. Por exemplo, recebemos, no início do ano para a la série um menino de rua. Mal sabia escrever o nome. Foi para a CA 
[classe de aceleração], se integrou com os outros alunos mais velhos e hoje está muito bem. É claro que não está 100\% para acompanhar uma $5^{a}$ série, mas evoluiu. O importante não é o tanto que aprendeu, a quantidade, mas o que ele conseguiu estando na CA.

Teríamos muitos outros depoimentos semelhantes que nos permitem afirmar que a equipe de direção escolar é um fator chave no sucesso do projeto.

\section{O trabalho nas salas de aula de aceleração}

As observações das salas de aula das turmas de aceleração levam-nos a afirmar que as relações construídas entre professor e alunos são bastante propícias à aprendizagem. Os alunos realizam as atividades num clima de tranqüilidade e respeito mútuo. Demonstram ter desenvolvido uma organização adequada para a efetivação do trabalho escolar e autonomia na realização das tarefas. Seguem alguns extratos de nossas observações, que nos levam a afirmar:

Na escola $M$, durante a realização de uma atividade de matemática, a professora chega perto de cada aluno, olha o que está fazendo, faz pergunta, orienta, elogia em voz alta os acertos.

Na escola $D$ uma das professoras mantém, em classe, o tom de voz baixo e pausado. Mostra-se carinhosa, alegre e são constantes seus contatos físicos com os alunos (abraços, beijos, afagos), além dos elogios que faz a cada participação deles. A outra professora procura enfrentar os problemas de disciplina sendo carinhosa, valorizando muito os acertos, elogiando os progressos de cada um.

$\mathrm{Na}$ escola A, a experiência da professora e o gostar de desafios parecem ser importantes ingredientes no sucesso de seu trabalho. Diz ela: "conhecer a história de cada um permitiu um trabalho de levantar a moral deles e agir sobre a auto-estima". O reforço escolar realizado três vezes por semana junto aos alunos com maiores dificuldades tem facilitado o trabalho, diz ela. Apesar de sentir dificuldades para desenvolver atividades diferenciadas, o que tem ajudado é o contato individual com os alunos, explica ela. Percorre os grupos e vai anotando a produção de cada um. A partir das anotações, prepara o reforço.

O professor da escola J diz que procura desenvolver a autonomia dos alunos. E exemplifica: "Eles guardam o material dentro das pastas. Arrumam os armários. Em todas as atividades dadas, observo os alunos, procurando orientá-los quanto aos erros, hipóteses".

A professora da escola D resume em que consiste o trabalho de sala de aula: "A gente trabalha com projetos e consiste em você assistir esses alunos naquilo que eles têm de mais carência...são projetos direcionados, montados nesse sentido de atender às dificuldades maiores deles. Vai desde começar a leitura, escrever um texto, desde esmiuçar o mais simples, mas tudo de uma maneira gostosa, não é nada pesado, nada que não atraia o aluno...o projeto procura envolver, melhorar a auto-estima deles, porque são alunos que tem auto-estima lá embaixo, por terem repetido, por virem de experiência negativa.

Não foram observadas situações de conflitos ou problemas sérios de conduta. Ao contrário, nos depoimentos das professoras, dos alunos, dos pais, da coordenadora pedagó- 
gica e da supervisão aparecem muitos exemplos de mudanças, sempre positivas, no comportamento dos alunos, seja em relação à sua auto-estima seja referente aos ganhos de aprendizagem. Como exemplo, citamos a fala de uma das mães da escola A sobre as mudanças que observou em sua filha: "Parece que ela ficou mais curiosa depois que entrou nessa classe. Antes ela não lia nem aquelas letrinhas nos filmes, ficava só assistindo. Agora eu não aguento de tanto que ela fala. Faz diferença estudar nessa classe". Outra mãe, da mesma escola diz: "A E... não gostava de estudar, não se interessava, chorava e eu pegava a cinta e obrigava ela vir. Agora ela não quer perder um dia de aula". A mãe de um aluno da escola C escreveu um bilhete para a professora, em que diz: "Agradeço de todo coração tudo que a senhora fêz pelo meu filho até agora, quero que a senhora saiba que o Luciano gosta muito da senhora".

Observamos que o material didático do projeto é bastante usado em sala de aula. Aliás, a qualidade do material didático foi ressaltada por todos os entrevistados, sem exceção. Uma de suas virtudes é a possibilidade de atendimento às diferenças no processo de aprendizagem, algo que vem sendo enfatizado por Perrenoud (1996, 1997) e Perraudeau (1997) como de fundamental importância para um ensino de qualidade. A coordenadora pedagógica da escola A considera que a "base da CA tem sido o material, os projetos...Se tivesse que destacar um trabalho que deu e vem dando muito certo, citaria o projeto com as caixas de remédios. Bem a calhar num momento de falsificações. Um projeto que integrou muitos conteúdos".

Observamos ainda que os professores seguem de forma muito flexível as orientações do material, levando em conta a realidade dos alunos, fazendo adaptações e sendo bastante criativos. $O$ depoimento de uma professora ilustra bem a necessidade de envolvimento do professor no trabalho:

A aceleração já traz o planejamento pronto, mas o meu é diário. Pego uma coisa aqui e outra ali. $O$ professor para pegar a aceleração tem que estar a fim de trabalhar mesmo, trabalho extra-classe. Tem que ter tempo mesmo. Todo dia tem que ficar registrando, planejando. Nem de longe isso é uma prática comum dos professores. (Depoimento da uma professora da escola A)

As observações feitas nas escolas e os depoimentos de todos os entrevistados nos levam a afirmar que um professor dedicado, experiente, disposto a estudar e a aprender, contando com bom material e apoio pedagógico adequado são fatores chaves no sucesso do projeto.

As opiniões dos agentes sobre o projeto

A opinião de todos os envolvidos no projeto é, em geral, muito positiva seja dos agentes que atuam diretamente na escola, seja dos pais dos alunos, seja dos agentes que supervisionam e apóiam a ação escolar.

A fala da dirigente regional da escola $M$ expressa de forma clara o que outros colegas também dizem sobre o projeto: "É um resgate do ser humano, a gente vê as crianças 
desabrocharem, falando em obras de arte, de visitas a museus, de poesias... Vê as crianças voltarem ao seu desenvolvimento normal. É um projeto muito bem-sucedido".

O supervisor da escola J acha que o mais interessante deste projeto é você perceber que o aluno da classe de aceleração faz uma leitura de mundo bem diferente hoje. A supervisora da escola M também concorda que "é um dos projetos mais sérios que vi nesses meus 25 anos de exercício porque mexeu nas pontas. Trabalha com o professor, mas trouxe material para o aluno. Tem aspectos filosóficos, mas traz também o como fazer, que é a grande dificuldade". E acrescenta: "Além disso, o projeto das CA tem um lado humano muito bonito: valorização do ser humano, pois considera toda criança capaz de aprender".

A assistente técnica de uma Delegacia de Ensino, responsável pela capacitação de professores das CA, também enfatiza a filosofia que orienta o projeto:

...diferentemente de momentos anteriores, não veio somente para diagnosticar a legião de repetentes e evadidos do sistema escolar, veio sobretudo para dar resposta ao que fazer com esses alunos. $\bigcirc$ sucesso do projeto não está ligado ao material necessariamente. $\bigcirc$ material é um suporte. Independente do material o importante é a nova filosofia que está sendo implantada: a progressão continuada.

As professoras das CA falam do desafio enfrentado a cada dia, seja para trabalhar com as atitudes: "A minha maior dificuldade é com relação ao relacionamento deles no dia-a-dia, de indisciplina, falta de respeito" (profa. da escola D); seja para trabalhar com as diferenças:

....são 25 alunos diferentes, 25 problemas diferentes. Trabalho com dinâmicas diversificadas. Trabalho com todos, atendo a cada um individualmente. Desenvolvo o trabalho entre as crianças, um ajuda o outro. O colega que é mais rápido, que tem mais condições de ajudar, ajuda o outro. Meu trabalho é diversificado, trabalho oralidade, leitura e escrita. Isso levanta a auto-estima dos alunos e dos professores. (Professora da escola A)

As professoras também destacam os progressos dos alunos e manifestam sua satisfação ao verem "um rapaz de 17 anos que não lia nada, lendo. $\bigcirc$ mais importante é ver o aluno se sentindo capaz de aprender. É uma mudança na auto-estima" (professora da escola C).

Os pais se emocionam ao falar das mudanças que observam em seus filhos, apontando o reflexo do sucesso escolar na sua vida cotidiana. A mãe de duas alunas da escola J, assim se expressa:

Não faziam nem o "a", não sabiam nada. No primeiro ano copiavam malfeito. Agora já estão lendo. A J. escreve um bilhete sem erro, a B. ainda erra alguma coisa. Em casa elas fazem tudo, até cozinhar quando é preciso. Antes elas não conheciam nada e não faziam compras. Só começaram a fazer depois de freqüentarem a classe de aceleração. Eu estou satisfeita. Eu pensava que elas não iam aprender a ler.

A mãe de um aluno da escola C relata o seu sucesso: "Essa classe foi ideal. Meu filho ficou na escola do sítio dois anos e não sabia escrever o nome. Agora sabe e lê melhor que 
o meu que está na $5^{a}$ série". As mães da escola M relatam mudanças nos filhos não só em relação a conteúdos aprendidos: "está lendo...está escrevendo melhor", mas também em relação a atitudes para com o estudo: "ele se interessa mais em fazer atividades... tem mais interesse em pesquisar".

Ao serem indagados sobre como se sentem nas classes de aceleração os alunos também deram depoimentos contundentes sobre os seus progressos:

Eu não sabia ler, não sabia escrever. Aprendi a ler e a escrever, escrevo carta. Na outra sala a professora brigava muito. $O$ professor $C$. é mais calmo. $O$ que a gente não sabe ele explica certinho e a gente vai aprendendo sozinho. Ele espera até a gente entender. $\bigcirc$ professor montou uma biblioteca e o professor empresta um livro e eu faço estórias com as perguntas que ele faz. (Aluno de 12 anos da escola J)

De um dos alunos da escola D ouvimos o seguinte depoimento: "Eu já tinha perdido as esperanças de aprender! Agora eu sei que sou capaz". Os alunos da escola M gostam da classe de aceleração "porque a professora faz a gente aprender. Ela tem paciência, fala perto da gente". Um egresso da classe de aceleração da escola A fala de sua experiência:

Gostei de tudo. Eu era ruim pra ler. Mas acho que melhorei muito. Era bom... mas enforcava aula. Agora que estou vendo que é ruim não saber ler e escrever bem, porque não arrumo serviço. As matérias eram boas. Tinha ajuda da professora e dos colegas e eu não aproveitei. Aprendi um pouco... mas faltava muito. Fazia muita pintura, cópia, continha, leitura. Tinha histórias, jogo e corrida das letras. A gente fazia em duplas. Era a mesma professora que tenho agora. Lá eram poucos alunos. Agora são 40 e eu não gosto.

Em resumo, os agentes escolares destacam como aspectos positivos:

- a proposta pedagógica com ênfase no material, considerado muito bom;

- o número menor de alunos em sala de aula que possibilita um atendimento individualizado;

- a possibilidade de que alunos multirrepetentes possam aprender e progredir em sua escolaridade;

- a possibilidade de o professor aprender como ensinar de modo eficiente;

- o acompanhamento do professor tanto em termos de capacitação para a realização de atividades em sala de aula, quanto em termos de orientação durante o processo;

- a segurança dos professores na realização de suas atividades e o apoio dado pela estrutura da escola e pela Delegacia de Ensino;

- a disponibilização aos professores de um novo espaço de discussão de suas dificuldades; 
- avaliação no processo com valorização de acertos e não dos erros dos alunos;

- ênfase na auto-imagem positiva do aluno e na sua capacidade de resolver situações do dia-a-dia de sala de aula.

Observou-se de maneira geral um discurso muito favorável por parte de todos os envolvidos diretamente com o projeto. Também foi unânime a afirmação de que as condições do projeto deveriam se estender a toda rede de ensino, especialmente o material considerado de ótima qualidade, assim como o suporte pedagógico oferecido ao professor pelos encontros periódicos de acompanhamento.

\section{Resultados em termos de aprendizagem dos alunos}

Só o fato de conseguir que esses alunos não se evadam, mas possam passar por experiências que os ajudem a resgatar a sua auto-estima, voltando a acreditar na sua capacidade de aprender, já seria uma grande contribuição do projeto das classes de aceleração. Mas seu impacto parece ir mais longe. As observações de sala de aula nas seis escolas, assim como os resultados das provas de desempenho e auto-estima aplicadas em três delas permitem dizer que o projeto vem tendo êxito ao levar a grande maioria dos alunos a um resultado similar aos das classes regulares. Mais do que isso, as observações revelaram que os alunos das classes de aceleração desenvolveram atitudes adequadas para a realização das tarefas escolares, movimentando-se de forma organizada no espaço de sala de aula, desenvolvendo os trabalhos com interesse e autonomia, e demostrando cooperação e respeito tanto em relação aos colegas quanto em relação à professora. Esses comportamentos são fundamentais para que ocorra aprendizagem.

\section{Os fatores de sucesso do projeto}

O sucesso do projeto parece estar ligado a diferentes âmbitos, entre os quais cabe destacar:

\section{Secretaria Estadual de Educação}

- o projeto se insere numa perspectiva político-pedagógica. Orientado por princípios que se fundamentam em dados de pesquisa, o projeto define metas a serem alcançadas no sentido de diminuir a evasão e o fracasso escolar e de dar condições para que as crianças com atraso de escolaridade possam recuperar a auto-estima e retomar, com sucesso, o percurso escolar estabelecido no sistema. $\bigcirc$ projeto inclui material pedagógico de excelente qualidade e em número suficiente para todas as escolas envolvidas, acompanhamento contínuo e competente das ações desenvolvidas nas escolas por parte das delegacias e da supervisão.

\section{Delegacia de Ensino}

- suporte competente oferecido às escolas, principalmente por parte do supervisor. As observações e entrevistas feitas evidenciaram o grande envolvimento da supervi- 
são no projeto. Visitam escolas, participam de reuniões pedagógicas, tiram dúvidas, conhecem os alunos pelos nomes, visitam salas de aula, orientam professores em temas específicos de alfabetização e matemática e organizam ações capacitadoras de acordo com as necessidades do grupo. Todos os entrevistados ressaltaram o importante papel da supervisão e das oficinas pedagógicas para o encaminhamento dos problemas encontrados no desenrolar do projeto e o apoio constante recebido, seja por meio das orientações técnicas, seja pela valorização do trabalho de toda a equipe escolar.

\section{Escola}

- equipe de direção escolar presente, atuante e comprometida com o projeto. Em todas as escolas observou-se que a direção ou vice-direção e a coordenadora pedagógica estavam sempre presentes na escola, conheciam o projeto, participavam das capacitações na Delegacia de Ensino, definiam um período das reuniões para as professoras das classes de aceleração exporem seu trabalho, visitavam as salas, conversavam com os alunos, chamavam os pais dos faltosos.

Professor

- disposição para enfrentar situações novas e vencer desafios. As observações mostraram que em todas as escolas os professores orientavam individualmente os alunos, valorizavam seus acertos, estimulavam a interação e o trabalho em grupo, registravam os progressos e as dificuldades de cada um, corrigiam, definiam limites, discutiam temas relacionados à sua vida cotidiana. Trabalhavam com atividades diferenciadas, tinham um planejamento flexível, faziam mudanças no material e nas atividades previstas pelo projeto.

\section{ESTUDO DOS ALUNOS EGRESSOS DAS CLASSES DE ACELERAÇÃO}

Estudo 2

Neste estudo, buscou-se, em uma amostra de alunos egressos, verificar seu rendimento, postura em classe, nível de participação e auto-estima, comparando-os com os demais alunos da classe.

A proposta inicial envolvia 10\% dos alunos que, em 1998, estavam cursando $4^{\mathrm{a}}$ ou $5^{\mathrm{a}}$ série e que haviam freqüentado classes de aceleração em 97, um total aproximado de 3. 100 alunos, distribuídos em 60 escolas. Esse total, porém, não se concretizou, pois :

- a listagem de escolas, contendo o número de alunos egressos de classes de aceleração, por série, oferecida pelas delegacias de ensino à Fundação para o Desenvolvimento da Educação, apresentava um número de egressos que, no 
momento da aplicação, se revelava muito menor (por vezes, I/3 ou I/4 do total previsto);

- para fazer a análise comparativa de desempenho, o grupo de não egressos deveria conter, preferencialmente, o mesmo número que o de egressos.

Assim, o número total de alunos avaliados - entre egressos e não egressos, foi de 1954.

Na seleção das escolas, foram levados em conta os seguintes critérios:

- terem pelo menos 20 egressos entre seus alunos de $4^{\text {a }}$ e $5^{a}$ séries;

- terem representação regional, incluindo escolas na capital, na Grande São Paulo e no interior.

Os dados referentes aos egressos foram solicitados pela FDE às delegacias de ensino. $\bigcirc$ exame das listagens contendo o número de egressos por escola e sua distribuição por série e por turmas, permitiu-nos selecionar as 54 escolas $^{2}$ para o estudo, assim distribuídas: 16 na capital e Grande São Paulo, I 5 no Vale do Paraíba, 5 na Baixada Santista e 18 no interior do estado, abrangendo as regiões de Rio Claro, Araraquara, Ribeirão Preto e Jundiaí.

A coleta de dados incluiu:

- primeiros contatos para acesso às escolas (carta de apresentação das Coordenadorias de Ensino do Interior e Grande São Paulo - CEl e COGSP);

- caracterização de cada escola, com dados relativos ao contexto físico, recursos humanos, forma de organização do trabalho pedagógico e visão do Projeto das Classes de Aceleração;

- aplicação de provas de Português e Matemática a todos os egressos de classes de aceleração e a igual número de não egressos da mesma série;

- aplicação, a todos os alunos submetidos às provas acima - portanto, egressos e não egressos - do inventário de auto-estima;

- entrevistas com:

- professores da classe de aceleração e da classe de egressos,

- diretores e/ou com coordenadores pedagógicos,

- alguns dos dirigentes regionais, conforme sua disponibilidade;

- contatos informais com supervisores de ensino.

2. O trabalho com as seis escolas do estudo de caso completa a amostra prevista de 60 escolas. 
Para a verificação do rendimento dos alunos, foram utilizadas provas de Português e Matemática, além de entrevistas com os professores. Os testes de desempenho foram os do Sistema de Avaliação do Rendimento Escolar do Estado de São Paulo - SARESP - 4ª série de Português e Matemática, de 1997 e os do Sistema de Avaliação do Ensino Básico - SAEB - $5^{a}$ série, Português e Matemática, de 1994. A razão da escolha desses testes foi o pouco tempo disponível para validação de novos instrumentos. Como os testes do SARESP e do SAEB já tinham sido validados e não eram conhecidos pelos alunos envolvidos na pesquisa e como seus itens medem habilidades muito similares às trabalhadas pelos professores nas classes de aceleração, optou-se pela sua aplicação. A utilização de provas de Português e Matemática foi decidida pela necessidade de se conhecer alguns dados concretos de desempenho desses alunos, para além das informações que poderiam ser colhidas na própria sala de aula.

Nas escolas com egressos cursando $4^{\text {as }}$ séries, foi entrevistado um professor (o docente da classe) e, em escolas com egressos cursando $5^{\text {as }}$ séries, dois professores (os docentes de Língua Portuguesa e Matemática).

A todos os alunos, egressos e não egressos, foi aplicada uma escala de auto-estima, com o objetivo de identificar as atitudes dos alunos em relação a si mesmos, aos colegas, à tarefa de casa e à escola, entre outras. $\bigcirc$ teste de auto-estima constou de uma adaptação do Measures of Self-Concept, grades k- /2, elaborado pelo Instructional Objectives Exchange, de Los Angeles, Califórnia (edição revista de 1972), gentilmente cedido pelo Núcleo de Avaliação Educacional, da Fundação Carlos Chagas.

Houve boa receptividade por parte de todas as escolas. O número de visitas a cada escola variou segundo a disponibilidade dos agentes educacionais para atender aos pesquisadores e de acordo com a maior ou menor facilidade de acesso aos dados.

Pressupondo que os alunos que freqüentaram as classes de aceleração estão melhor do que estavam antes de participarem do projeto, a pesquisa buscou atender à questão posta no documento Avaliação (São Paulo, 1998a, p.4I) que indaga: "(...)seriam os avanços realizados suficientes para que [os alunos] sigam sua trajetória escolar com sucesso?"

Desta forma, os dados coletados buscam verificar se os alunos egressos das classes de aceleração e que já foram reintegrados ao sistema regular de ensino apresentam desempenho compatível ao dos demais alunos. Pretende-se também identificar o posicionamento dos professores e diretores dessas escolas em relação às propostas do Projeto Classes de Aceleração.

A análise de cada um dos conjuntos de dados coletados permitirá melhor compreensão da situação e da dinâmica dos alunos egressos, nas relações consigo mesmos e com os colegas, com o conhecimento e com seus professores.

Análise dos resultados do Inventário de Auto-Estima

A auto-estima é uma característica humana difícil de ser estudada e avaliada, dada a complexidade das inter-relações que atuam na sua construção e transformação. É algo 
adquirido durante e por intermédio das relações interpessoais e fator condicionador do comportamento do indivíduo. Será afetada pela aceitação ou rejeição que o indivíduo goza entre seus pares e entre aqueles com quem convive. Além disso, a posição que cada um ocupa no grupo está relacionada com o rendimento de cada membro do grupo. Sendo assim, há que se considerar as influências exercidas pelo professor, pelo grupo de pares e pelo ambiente da escola no desenvolvimento da auto-estima dos alunos.

Um dos aspectos centrais do Projeto Classes de Aceleração diz respeito ao cuidado dispensado à questão da auto-estima dos alunos atendidos. A defasagem de idade em relação à série em que os alunos estão matriculados vem acompanhada de um conjunto de problemas, seja de ordem da aprendizagem ou das relações interpessoais, seja de questões relacionadas à auto-estima.

Ao se recuperar a trajetória dos alunos em situação de defasagem, não apenas se busca atender à sua reintegração ao sistema escolar, mas também à superação de rótulos e estigmas que esses alunos carregam e ao seu direito de usufruir de um ensino de qualidade. Fruir esse ensino não é apenas obter sucesso e rendimento acadêmico, mas também acreditar-se capaz desse sucesso, capaz de enfrentar situações escolares e não escolares com confiança, com iniciativa, cooperando com seu próprio desenvolvimento e participando do desenvolvimento social (São Paulo, 1997, p.7-9).

O Projeto Classes de Aceleração procura se apoiar em uma expectativa positiva das possibilidades do aluno, ao lado do aumento da competência da escola (São Paulo, 1997, p. 10). Na interação sujeito-conhecimento, intervêm de maneira importante os significados que o aluno atribui a essa interação e a percepção que ele tem das possibilidades de que esse conhecimento passe a ter sua marca. Assim, ao lado de atividades ricas ligadas ao conhecimento, as oportunidades de diálogo, de expressão, de interação grupal e de avaliação, os projetos visam também ao desenvolvimento da auto-estima.

Após um ano de trabalho com os alunos das classes de aceleração, estes, reintegrados às classes regulares, foram avaliados por meio de um Inventário de Auto-Estima (1972). A auto-estima é definida como "a representação consistente que o indivíduo tem de si mesmo, abrangendo todos os atributos, traços e características de sua personalidade" (Fundação Carlos Chagas, 1998, p.76). A imagem que o indivíduo faz de si mesmo está relacionada à interpretação que dá às suas experiências cognitivas e sociais e à interpretação que dá às informações recebidas de outras pessoas durante suas experiências sociais. A auto-estima diz respeito ainda à consciência de si mesmo, ao ver-se e avaliar-se. Envolve sentimentos em relação a si mesmo, ao que se acha capaz de fazer, à sua segurança em relação a si mesmo, aos outros, ao mundo.

Quando esses sentimentos e pensamentos são positivos, diz-se que a pessoa tem alta auto-estima. Quando são negativos, isto é, a pessoa não se valoriza, não se acha capaz de realizações ou de alcançar sucesso, não se sente confiante para agir ou arriscar-se, diz-se que 
tem baixa auto-estima. Esses pensamentos e sentimentos se referem a várias dimensões da personalidade da pessoa e estão na base das ações que ela realiza no seu meio e nas relações que estabelece consigo mesma e com outras pessoas.

Assim, a compreensão e avaliação de si mesmo são muito importantes na escola, uma vez que o desempenho reflete, em certa medida, o nível de auto-estima e, em contrapartida, essa auto-estima contribui para as modificações nesse nível. O documento Avaliação, da série Ensinar pra valer! Aprender pra valer! (São Paulo, 1998a, p.38-9) identifica, no processo do desenvolvimento do autoconceito, marcos que estão na base da concepção de auto-estima, tal como ela está definida aqui: o aluno é capaz de aprender, de enfrentar desafios, participar cooperativamente nos grupos, ter persistência e autonomia. E esses marcos estão relacionados a questões importantes quanto ao trabalho do professor, para que um autoconceito positivo se desenvolva.

A aplicação do inventário permitiu identificar o nível da auto-estima dos alunos egressos e não egressos das classes de aceleração, nas dimensões familiar, social, individual, escolar e geral. As dimensões consideradas refletem as relações que esses alunos estabelecem entre os diversos âmbitos de sua vida e como se posicionam, em cada um deles: quão seguros, confiantes, expectantes, tranqüilos se sentem quanto às suas relações no meio familiar, social, nas suas percepções e sentimentos em relação a si mesmos e aos outros, nas diferentes situações da sua vida.

Os inventários foram estudados estatisticamente, possibilitando comparar dados de alunos de $4^{a}$ e $5^{a}$ séries das Coordenadorias de Ensino da Grande São Paulo e do interior.

Assim, comparando-se alunos e alunas, percebe-se que não há diferenças relevantes entre os sexos, nos dois níveis mais baixos (auto-estima negativa) e mais altos (auto-estima positiva), o mesmo se podendo dizer dos dados oriundos de CEI e COGSP: serem da Grande São Paulo ou do interior do estado não influencia os resultados.

No entanto, quando se analisam os dados referentes a alunos egressos e não egressos, observa-se que os não egressos têm maior porcentagem do nível mais alto de autoestima geral, 46\% (auto-estima positiva), em relação aos egressos, 23\%. E estes têm maior porcentagem do nível mais baixo de auto-estima geral, $41 \%$ (auto-estima negativa), que os não egressos, $21 \%$. E estas relações se mantêm quanto a cada uma das dimensões de autoestima considerada (familiar, social, individual, escolar).

Vale destacar que, na auto-estima em relação ao aspecto escola, os egressos apresentam uma porcentagem de 39\% do nível mais baixo (negativa) de auto-estima, versus 29\% do nível mais alto (positiva), enquanto essas porcentagens, nos não egressos, são de, respectivamente, 22 e 46\%. Assim, destaca-se o fato de que, em sua trajetória na classe regular, os egressos apresentam mais baixa auto-estima.

O que chama a atenção de maneira forte é a evolução da auto-estima, em relação à idade. A avaliação do conjunto de alunos egressos e não egressos estudados revela, primei- 
ramente, um aumento da baixa auto-estima, à medida que aumenta sua idade - $10 \%$ aos 10 anos e 44\% aos 15 anos, e uma diminuição do nível de alta auto-estima, também na mesma seqüência: $60 \%$ aos 10 anos e $24 \%$ aos 15 anos, parecendo indicar uma tendência marcante: quanto menor a idade, maior a porcentagem do nível de alta auto-estima e menor a do nível de baixa auto-estima e, à medida que a idade aumenta, tende a diminuir a alta auto-estima e aumentar a baixa. Uma vez que, considerando a idade, a tendência geral - de egressos e não egressos - é a mesma, faz-se necessário relativizar os baixos resultados quanto à auto-estima dos egressos. Estes, pelas múltiplas repetências ou saídas e reingressos no sistema, são mais velhos do que os alunos não egressos, o que explicaria uma maior freqüência de baixos resultados no inventário.

Na análise da distribuição percentual dos alunos, por níveis, na escala do Inventário de Auto-Estima, segundo a Coordenadoria de Ensino, o tipo de aluno e a série que freqüenta (Gráfico I), os níveis de auto-estima, nomeados I, 2 e 3, do mais baixo para o mais alto, apresentam alguns aspectos que chamam a atenção:

\section{GRÁFICO I}

DISTRIBUIÇÃO DOS ALUNOS, POR NÍVEIS, NAS ESCALAS DO INVENTÁRIO DE AUTO-ESTIMA, SEGUNDO O GRUPO A QUE PERTENCEM: GERAL

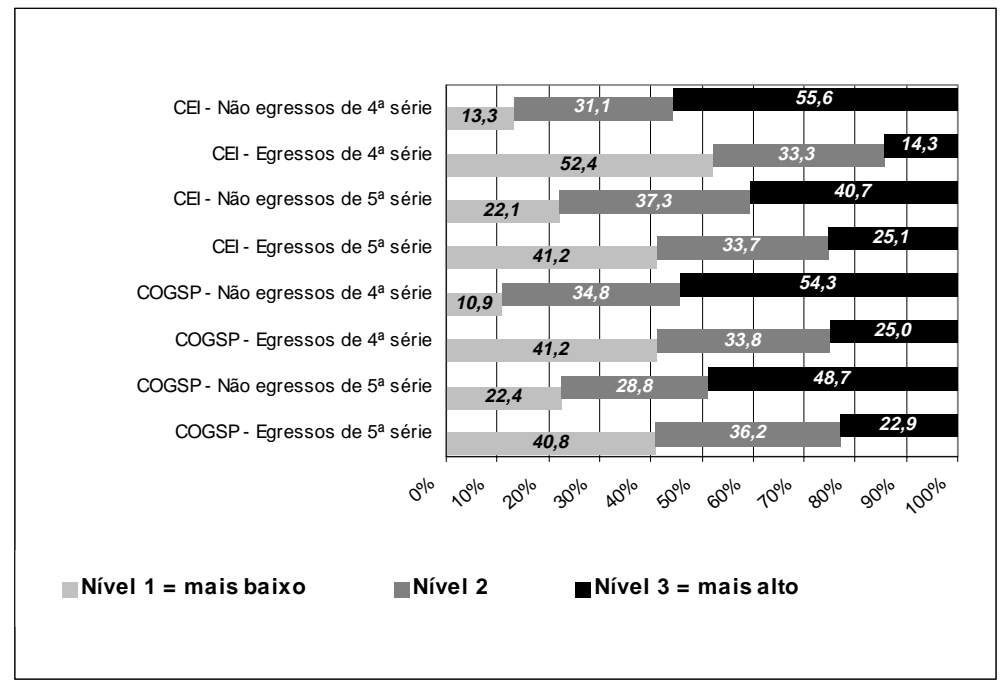

Não há diferenças importantes entre alunos egressos e não egressos, quanto à Coordenadoria de Ensino a que pertençam, COGSP ou CEI (no mínimo 0,3\% e, no máximo, $11 \%$ de diferença). Nesse caso, o nível de baixa auto-estima de alunos egressos de $4^{a}$ série da COGSP ficou em 4I ,2\%, enquanto esse mesmo nível, entre os egressos de $4^{\mathrm{a}}$ série da CEl, ficou em 52,4\%. Ambas as porcentagens são significativamente altas, indicando baixo nível de auto-estima desses alunos. 
Não há diferenças relevantes entre os índices de auto-estima dos alunos egressos de $4^{\mathrm{a}}$ e $5^{\mathrm{a}}$ séries, tanto da COGSP quanto da CEI. No entanto, entre os não egressos, diferenças entre $4^{\mathrm{a}}$ e $5^{\mathrm{a}}$ séries estão presentes, mostrando menor nível de baixa autoestima dos alunos de $5^{\mathrm{a}}$ série, na COGSP e na CEl e maior nível de alta auto-estima, entre os alunos de $4^{a}$ série da CEI (embora ainda com um bom percentual de 40,7\%, entre os alunos de $5^{\mathrm{a}} \mathrm{s}$ séries).

Há diferenças entre egressos e não egressos, sendo que os primeiros apresentam maiores índices do nível mais baixo de auto-estima e menores índices do nível mais alto de auto-estima. Não se pode falar em diferenças estatísticas significativas, mas pode-se, sem dúvida, marcar tendências importantes quanto a essas diferenças, embora com o cuidado de lembrar que os alunos egressos, em geral com idade mais avançada em relação aos não egressos, podem estar dentro do movimento anteriormente apontado: quanto maior a idade, menores os níveis de alta auto-estima.

A avaliação da auto-estima de alunos com defasagem idade/série (Fundação Carlos Chagas, 1998) mostra relação entre bons níveis de auto-estima positiva e resultados favoráveis no desempenho escolar. $\bigcirc$ que se encontra agora, nos alunos egressos, é uma concentração de resultados do nível mais baixo de auto-estima, o que nos incita a lançar questionamentos quanto a ocorrências nas classes regulares que pudessem gerar tal nível de auto-estima. Que relações podemos estabelecer entre esse resultado e o atendimento/ acompanhamento dos alunos realizado pelas escolas, se, nas classes de aceleração, professores e pais relatam situações positivas em relação à auto-estima dos alunos?

A análise das entrevistas com professores de egressos poderá contribuir para a compreensão desse quadro.

Análise dos resultados dos testes de desempenho

A análise do rendimento dos egressos, comparativamente ao rendimento de não egressos, foi uma metodologia escolhida para que se pudesse ampliar o conhecimento e a compreensão a respeito do impacto do Projeto Classes de Aceleração, a partir do conhecimento e compreensão de seus egressos.

Os dados resultantes dessa análise estão sintetizados no Gráfico 2, referente ao desempenho dos alunos egressos e não egressos, por coordenadoria, componente curricular, escola e série, tendo sido calculadas estimativas para as médias e a medida da variabilidade (desvio padrão).

Dado que os desvios padrão, tanto para Português quanto para Matemática, são pequenos, torna-se possível utilizá-los como referência para nossa análise. 
GRÁFICO 2

DESEMPENHO MÉDIO E VARIABILIDADE DOS DADOS POR GRUPO DE ALUNOS SEGUNDO A COORDENADORIA DE ENSINO, SÉRIE E PROVA

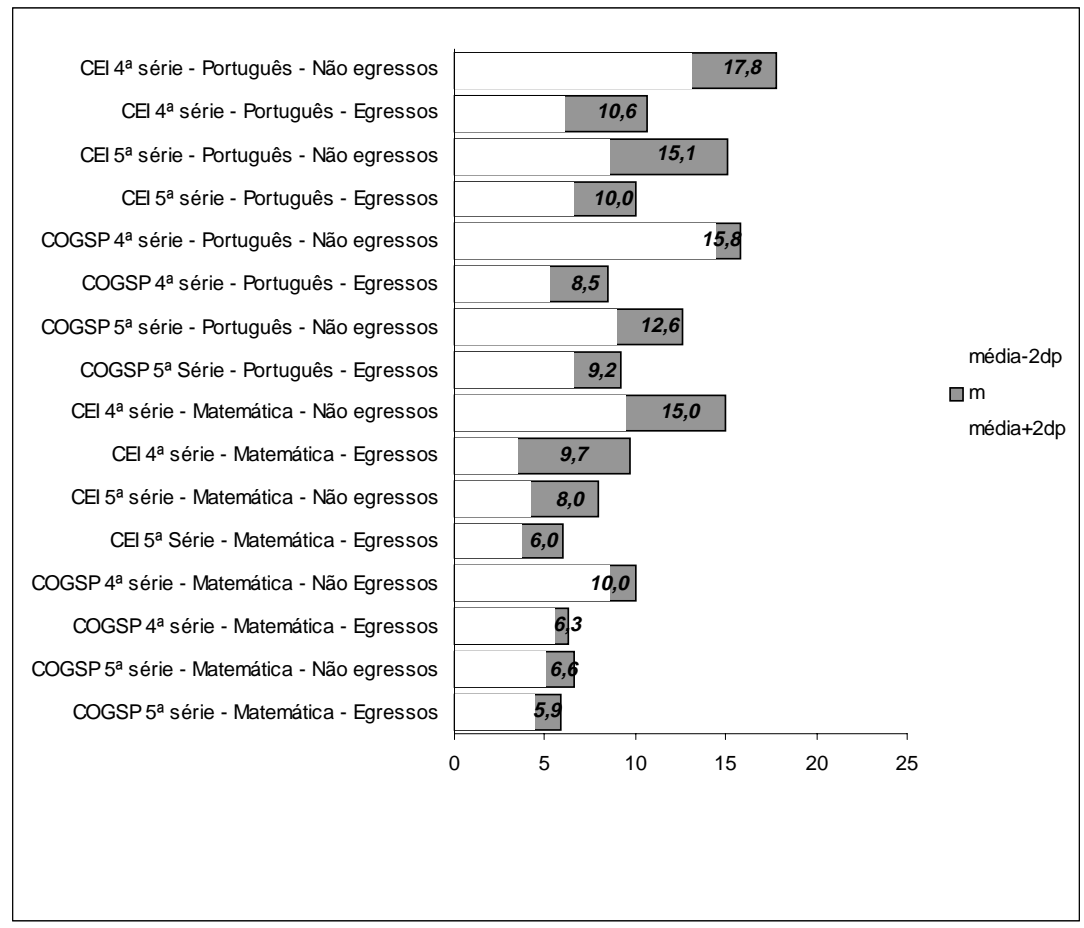

Português

Na quarta série, COGSP, a média de egressos foi de 8,5 com uma variabilidade de 1,6 e a média dos não egressos foi de 15,8 com uma variabilidade de 0,7. Considerando-se a medida de dois desvios padrão como fonte de comparação entre os grupos, pode-se considerar que há relevância na diferença de resultados. Quanto aos resultados de CEI, nesta disciplina e nesta série, a situação apresenta-se da seguinte maneira: egressos, média 10,6, com desvio padrão de 2,2 e não egressos, média de 17,8, com desvio padrão de 2,4. Essa diferença apresenta importância ainda que pequena. Em ambas as coordenadorias, são médios os resultados dos não egressos e baixos os de egressos.

Na $5^{a}$ série, na COGSP, a média de egressos foi de 9,2, com uma variabilidade de I,3 e a dos não egressos, foi de 12,6, com uma variabilidade de I,8. Os resultados de ambos os grupos foram baixos, e, considerando-se a medida de dois desvios padrão como fonte de comparação, pode-se afirmar não haver diferenças relevantes de resultados. 


\section{Matemática}

$\mathrm{Na} 4^{\mathrm{a}}$ série, COGSP, as médias e desvios padrão de resultados de egressos e não egressos foram, respectivamente: 6,3, desvio padrão 0,3, e 10, desvio padrão 0,7. Considerando-se a medida de dois desvios padrão como fonte de comparação entre os grupos, pode-se considerar haver uma diferença muito pequena de resultados. $\mathrm{Na} C E I$, na mesma série e disciplina, as médias e desvios padrão de resultados de egressos e não egressos foram, respectivamente: 9,7, desvio padrão 3, I, e 15, desvio padrão 2,7. No limite de dois desvios padrão, não se pode afirmar que há diferença entre os dois grupos.

$\mathrm{Na} 5^{\mathrm{a}}$ série, COGSP, as médias e desvios padrão de resultados de egressos e não egressos foram, respectivamente: 5,9, com desvio padrão 0,7, e 6,6 com desvio padrão 0,8. Também aqui os resultados dos dois grupos foram muito baixos e, ainda considerando-se a medida de dois desvios padrão como fonte de comparação entre os grupos, não há diferenças de resultados. $\bigcirc$ mesmo acontece com relação aos dados da disciplina, na CEl: egressos média 6,0, desvio padrão I,2, e não egressos média 8,0 e desvio padrão 1,9.

Em Matemática, as médias em geral estão mais baixas do que as de Português, podendo se considerar médios apenas os resultados de não egressos da CEl, na $4^{\mathrm{a}}$ série.

Neste breve estudo descritivo dos grupos, o que, de início, com os resultados brutos, parecia indicar grande desvantagem para os egressos de CA, do ponto de vista de desempenho nas disciplinas Português e Matemática, acabou por se constituir em ausência de diferenças ou, no caso de $4^{\mathrm{a}} \mathrm{s}$ séries, em diferenças muito pequenas (um pouco maiores em Português, entre alunos da COGSP de $4^{\mathrm{a}}$ série). As diferenças apontadas podem ser a concretização do que dizem os professores nas entrevistas: muitos alunos egressos chegam à classe regular semi-alfabetizados, com grandes dificuldades de leitura e entendimento de texto.

\section{Análise das informações das entrevistas com professores}

As visitas às escolas revelaram a existência de realidades diversas do ponto de vista pedagógico e organizacional, que variam desde escolas com dificuldades para criar um ambiente propício ao processo de ensino-aprendizagem, número excessivo de alunos por classe, ambiente físico limitado e situações de indisciplina, até escolas com número razoável de alunos por classe, espaço físico organizado, alunos tranqüilos e professores aparentemente satisfeitos.

É interessante destacar o caso de uma escola do centro da cidade de São Paulo, instalada num prédio de cinco andares aos quais se tem acesso por escada, com um pátio de cimento em um dos andares, com 2070 alunos, caracterizada pelos professores como clientela carente. $\bigcirc$ desempenho dos alunos egressos dessa escola, mesmo não tendo sido notável, foi o melhor em Português (39\%), comparado com o de outras escolas, e o melhor 
desempenho global (29\%), juntamente com outra escola. Nessa escola, chamou a atenção o fato de as pesquisadoras terem sido recebidas pelo próprio diretor, que demonstrou estar integrado e envolvido com todas as questões da escola, ser uma presença constante, com disponibilidade para conversar sobre a situação do ensino e sobre questões locais. Sua atitude revela, mais uma vez, que o compromisso da direção e a articulação que ela promove na escola são variáveis importantes para o sucesso dos alunos.

Os dados foram coletados em dezesseis escolas da COGSP, sendo entrevistados 27 professores, dentre os responsáveis por classes de $4^{a}$ série e pelas disciplinas de Português e Matemática de $5^{a}$ série. $\mathrm{Na} \mathrm{CEI}, 37$ escolas foram contatadas, das regiões de Araraquara, Ribeirão Preto, Jundiaí, Vale do Paraíba e Baixada Santista, tendo sido entrevistados 75 professores, igualmente responsáveis por classes de $4^{\mathrm{a}}$ série e pelas disciplinas de Português e Matemática na $5^{\mathrm{a}}$ série.

Nas entrevistas, os professores externaram seu conhecimento e opinião a respeito do Projeto Classes de Aceleração, sobre os alunos egressos, suas diferenças e semelhanças em relação aos alunos não egressos e comentaram as formas de trabalho com os alunos.

Na discussão dos dados, buscou-se inicialmente separar as escolas em dois grupos: reorganizadas (de $1^{\mathrm{a}}$ à $4^{\mathrm{a}}$, de $5^{\mathrm{a}}$ à $8^{\mathrm{a}}$, de $5^{\mathrm{a}}$ à $8^{\mathrm{a}}$ e médio) e não reorganizadas, na hipótese de que houvesse discrepância entre as opiniões dos professores conforme o tipo de escola. Poder-se-ia supor que nas escolas reorganizadas houvesse algum tipo de trabalho que possibilitasse melhor acompanhamento dos egressos do que nas não reorganizadas. No entanto, a análise dos depoimentos dos professores revela conhecimento/desconhecimento do projeto e dos alunos, tanto nas reorganizadas como nas não reorganizadas. Em decorrência dessa constatação, decidiu-se pela discussão conjunta das escolas, destacando-se determinados temas: conhecimento do projeto e dos alunos egressos, opiniões dos professores a respeito dos egressos e sua comparação com os não egressos, participação dos alunos egressos em aula, trabalho do professor e acompanhamento dos egressos.

Dos professores entrevistados, entre 50 e 60\% dizem conhecer o projeto. Os demais conhecem pouco ou quase nada sobre o projeto. As informações vão desde "conhecem bem o projeto" até "conhecem pouco", "não sabem quase nada", "ficou sabendo ontem", "só agora ficou sabendo que o projeto existe":

Peguei uma apostila em outra escola. Do que li da apostila, achei muito legal; na parte teórica é muito bonito. [...] Não conheço o projeto, só de ouvir falar. Até achei que, se era aceleração, era para mandar os bons alunos para a frente, mas depois vi que era para os atrasados. [...] Saber como funciona, não sei. [...] Na prática, não conheço nada do Projeto da Classe de Aceleração; conheço na teoria.

Outros, embora não conheçam o projeto, conhecem e apreciam o material nele utilizado. Outros ainda afirmam: "Conheço, mas não recebi nenhuma informação oficial." 
O desconhecimento dificulta a compreensão do aluno egresso e, conseqüentemente, a continuidade do trabalho, e ao lado do grande número de alunos por classe, constitui um dos fatores que criam maiores obstáculos ao bom desenvolvimento do trabalho, conforme apontam as entrevistas com os professores.

Acho um projeto muito bom, mas, para dar continuidade para os alunos, numa classe com 40 alunos, é difícil. E o trabalho anterior era muito dinâmico. Eles (os egressos) se sentem meio perdidos. $\bigcirc$ professor não consegue dar a atenção necessária.

Os professores que conhecem bem o projeto, julgam-no bom: "Conheço bem o projeto. Eu acho o projeto bem válido, pois temos alunos que estão fora da faixa etária de $5^{a}$ série e terão a oportunidade de acompanhar a turma de sua faixa etária". Mas mesmo sem conhecer bem, a maioria se manifesta pela validade do projeto: não fosse a classe de aceleração, muitas crianças "teriam abandonado a escola para trabalhar ou, quem sabe, mais provavelmente, teriam seguido o rumo do tráfico".

Alguns professores revelam gostar do projeto. Uma professora diz que o projeto é "legal, com parte teórica bonita, mas há distância entre o que li e a prática." Outra o considera "excelente, desde que tenha pessoal competente, material pedagógico e se faça um trabalho de qualidade." Outra ainda o considera muito bom, mas "difícil de dar continuidade."

porquê do conhecimento/desconhecimento do projeto é destacado em alguns casos:

.... interação aqui é difícil; as salas de aceleração são em outro prédio e o HTPC é separado; [...] Conheço bem o projeto, a coordenadora nos orientava; [...] procuro conversar com os colegas na HTPC e com a coordenadora; [...] conheci através da mãe de um aluno; [...] fiz o curso do projeto de classe de aceleração; [...] conheci através de duas pessoas da DE.

Nessas entrevistas com professores, ficou evidente ainda a falta de informações sobre os alunos. Muitos professores identificam os alunos egressos quase por acaso:

Tenho recebido alunos que têm uma deficiência incrível...Quando detectei o problema, mandei um bilhete para a mãe; a mãe veio e comentou que ele era de classe de aceleração. [...] Não sabia quem eram os egressos; fiquei sabendo no decorrer do ano, quando pedia algo e não correspondiam. [...] $\bigcirc$ ano começou, pegamos os alunos e não tivemos nenhuma informação sobre eles; nos deram e nos viramos. [...] Numa classe de 40 alunos, é impossível. Agora, se houver bom espaço e se houver atendimento individual... porque os alunos da classe de aceleração, a todo instante, querem comprovação do que fizeram. [...] O professor percebe e identifica os alunos - pela idade maior e porque estão desenturmados.

Alguns professores dizem conhecer os egressos (reconhecê-los?) pelo interesse e participação na aula; têm um cuidado especial com eles, mandando-lhes recados no caderno ou nos trabalhos, atendem às dúvidas individualmente e tentam fazer um trabalho diferenciado. 
No entanto, uma professora considera que os egressos, "por terem pulado etapas, percebem que têm deficiências, têm medo de se expor e têm dificuldade de participação." Além disso, é interessante observar que, numa das escolas, um professor que afirma não conhecer quem são os egressos, opina sobre os mesmos: "não participam das atividades, não têm notas nas papeletas, têm comportamento ruim", indicando claramente seu preconceito.

Muitos professores argumentam que os egressos são alunos mais lentos, porque vêm sem base para acompanhar a $5^{a}$ série. Não têm hábitos de concentração, de cumprimento de tarefas. Têm dificuldade na interpretação de textos, na ortografia, na leitura, não dominam as quatro operações, têm dificuldade de raciocinar. Mas alguns professores ressalvam: "Alguns dos não egressos são assim também." Um dos professores afirma que apesar da ortografia não estar dominada, o conteúdo é bom, e que "podem acompanhar, desde que bem trabalhados, porque são mais sensíveis que os não egressos". Outro professor afirma que dois alunos egressos são muito bons em Matemática; outro ainda, que "dos sete egressos da classe, quatro são bons". Um professor de Matemática comenta o trabalho com egressos em Geometria: nesta área, saem-se muito bem, sendo que numa atividade que envolvia criatividade na resolução de um problema, um aluno egresso foi o que apresentou a solução mais criativa (e correta), tendo sido seu trabalho escolhido para a exposição que a escola realizaria para a comunidade.

A maioria dos professores comenta a instabilidade dos alunos egressos quanto à freqüência; alguns lembram que a maioria se evade porque precisa trabalhar para ajudar a família, e os que trabalham e estudam à noite encontram muita dificuldade para conciliar as duas atividades. Um dos professores argumenta que não conseguir acompanhar a classe os deixa agressivos, briguentos.

No entanto, uma professora reconhece que não consegue dar-lhes a atenção necessária, em comparação com trabalho dinâmico anteriormente realizado nas classes de aceleração. Uma professora informa que "só ontem percebi quais eram (os egressos). Agora, vou prestar mais atenção." Esta situação, indicadora de ausência de envolvimento do conjunto dos professores no projeto, vai na direção oposta ao previsto no Documento de Implementação do Projeto Classes de Aceleração (São Paulo, 1998), que considera que "o sucesso na retomada do trajeto escolar pelos alunos das Classes de Aceleração por si só não garantirá o término da geração de novas defasagens. É importante que todos os professores da escola participem desse esforço..."(p.6), com o envolvimento de toda a equipe escolar no planejamento, acompanhamento e avaliação do currículo e do ensino.

Além disso, a Proposta Pedagógica Curricular do Projeto (São Paulo, 1997), definindo alvos a atingir, enfatiza "a necessidade de que se garantam possibilidades de seqüência, o que pressupõe o planejamento de aprendizagens facilitadoras do trabalho subseqüente e mais específico, por disciplinas...", o que implica o:

...envolvimento de toda a equipe escolar, para a elaboração de uma proposta integrada ao projeto da escola e direcionada à busca das aprendizagens fundamentais, partindo de fato do 
ponto em que os alunos estão, para daí prosseguir, dando impulso e continuidade ao processo de ensino-aprendizagem. (Idem, p.II)

As opiniões dos professores a respeito dos egressos e sua comparação com os não egressos são bastante discrepantes e, em alguns casos, parecem ter relação com o seu conhecimento/desconhecimento do projeto.

Assim, entre professores que conhecem o projeto, as falas valorizam aspectos como o maior interesse, dedicação e participação dos egressos; sua "postura para a aprendizagem", sua organização. São "mais tímidos, preocupados em aprender", "têm carisma e confiança no professor". No entanto, os professores reconhecem que esses alunos têm "mais dificuldades de leitura e interpretação", "não gostam de cálculo", mas "gostam muito de geometria", "não sabem tabuada"; "entendem a idéia, mas têm dificuldade de escrever", "muitos não são completamente alfabetizados e não conhecem as quatro operações". Finalmente, os professores percebem que os egressos "têm medo de mostrar que não sabem" e, "quando percebem que não produzem, perdem o estímulo e se ausentam", o que talvez explique as faltas desses alunos. Em alguns casos, a escola se organiza para descobrir por que o aluno falta ou se evade. Mas, em muitos casos, a escola nem mesmo está informada sobre o que está acontecendo com os egressos.

Dentre os professores que não conhecem o projeto - e até mesmo os que dele souberam "ontem" - (por meio da convocação para a entrevista desta pesquisa?), as falas dos egressos são menos valorizadoras e exprimem uma expectativa de desempenho que parece não levar em conta a realidade desses alunos. Assim se expressam os professores: "a gente pede e eles não correspondem". "O progresso não é o que eu queria". "São um pouquinho mais fracos; aprendem mais lentamente." Os professores dizem ainda que os egressos são "fracos de aprendizagem e de escrita", "não têm interesse e não estudam". "Faltam por desinteresse". Um professor considera seu relacionamento difícil e afirma: "Só fazem as coisas em grupo; estão sempre aos pares".

Em uma das escolas pesquisadas, os alunos egressos estão agrupados numa mesma sala, e as opiniões dos professores se dividem quanto ao acerto da medida. Uns consideram que reunir todos na mesma sala facilita o trabalho, e resolve o problema da diferença de idade em relação aos demais. Outros argumentam que deveriam estar espalhados pelas diferentes classes, pois não se diferenciam muito dos não egressos. Uma professora de Português afirma: "Eu comparei redação da $5^{a}$ série regular com a do egresso e não há grande diferença. Os egressos sabem menos Gramática, menos análise sintática, mas na produção de texto não há grande diferença".

Noutra escola, é relatada a experiência de 1997 quando foram agrupados todos os egressos numa mesma sala. Diz a diretora: "Os professores quase ficaram loucos, um até apanhou de aluno. Em 98, eu separei os alunos e os professores quiseram agrupá-los outra vez. Não concordei, mas não sei o que fazer. Tenho medo de prejudicar os alunos regulares". 
Nessa escola, o professor de Português, na entrevista, afirma que os egressos atrapalham o andamento da classe, que são indisciplinados e que ele "não aprendeu a trabalhar com aluno assim."

Quanto à participação em aula dos alunos egressos, uma opinião freqüente foi a de que são lentos e, para alguns professores, dispersos:

São bastante lentos e acomodados. [...] Os egressos são mais dispersos, não conseguem trabalhar em grupo. Para chamar a atenção, é complicado. Emburram facilmente... [...] Não sabem expressão oral.... Têm deficiência na rapidez de raciocínio... [...] Os alunos vindos de classe de aceleração são mais dispersos do que os outros. Eles, em geral, têm uma história de vida triste. [...] Eles são bem mais lentos.

Há algumas opiniões diferentes e até mesmo contrárias a essas:

Na participação, não há diferenças [entre egressos e não egressos], mas na aprendizagem, sim. Fazem os trabalhos em grupo, se interessam, mas, quando apresentam, não apresentam quase nada. [...] Os alunos, em geral, têm um maior interesse, maior dedicação, participam mais. A aprendizagem é boa, não demonstram lentidão no trabalho. Os que vêm com muita defasagem não acompanham, mas a grande maioria acompanha. Em geral, 60\% vão bem e $40 \%$ vão mal. [Esta última fala é de uma professora que conhece o projeto.]

Quanto ao seu relacionamento, participação e empenho, não há diferenças marcantes entre egressos e não egressos, embora haja ligeira vantagem para os egressos, nos quesitos "participação e interesse", segundo alguns professores.

Em síntese, nas considerações dos professores, são mencionadas com ênfase as dificuldades de aprendizagem dos alunos e sua falta de pré-requisitos importantes quanto ao conhecimento - embora, ainda pela fala dos próprios professores, não tão diferentes das dificuldades dos alunos não egressos. Chama a atenção, no entanto, que, em uma escola, dois egressos foram reclassificados para a 6 a série e, segundo o professor, "estão ali, iguais aos outros".

Em relação ao trabalho do professor, não há referência à utilização de uma metodologia diferenciada para o atendimento aos egressos. As atividades propostas - participação de trabalhos em grupo e individuais, pesquisas, resolução de problemas, trabalho com o concreto, avaliação contínua, verificação de tarefas, trabalho em duplas (um fraco e um forte) - são as mesmas para qualquer aluno, na fala de todos os professores.

Há casos em que se percebe que os professores estão fazendo o que sabem e o que podem:

Estou tentando fazer um trabalho diferente; quatro não acompanham nada e, com eles, faço um trabalho à parte na sala de aula. [...] $\bigcirc$ conteúdo eu não mudo, mas eu vou mais devagar com eles. A forma de trabalhar com os de aceleração é diferente [não diz qual é]. 
Ao final, chegamos ao mesmo conteúdo de outras classes. [Essa escola formou uma classe só com egressos.]

Alguns afirmam empenhar-se em fazer um trabalho diferenciado e necessitar de capacitação para um melhor atendimento; há os que buscam a integração com seus pares para um melhor trabalho; outros ainda, pensam que falta união entre os professores e que isso dificulta sua atuação. Uma professora, que possui Mestrado em Educação Matemática, manifestou sua insatisfação por reconhecer ter sido autoritária muitas vezes para conseguir a disciplina na classe composta, na sua maioria, por egressos. Ao informar que mandam para reforço os alunos que não vão bem, alguns professores reclamam que "não há integração para o planejamento do reforço".

Uma outra professora diz avaliar cada atividade e "fazê-los refazer o que está errado". Como "os alunos adoram ser desafiados, é por aí que eu vou". Um dos professores diz que explica "para todos, pois nem identificava os egressos".

O que fica claro é que os professores não sabem como poderiam agir diferentemente em relação aos egressos. Expressam sua opinião de que seria necessário ter mais informações sobre eles e sobre o projeto. Nenhum professor se refere à comunicação intencional de dados sobre os egressos, pela equipe pedagógica. É de se supor (o Projeto Classes de Aceleração previa) que os professores das classes de aceleração tivessem dados interessantes sobre seus alunos - e esses dados poderiam ter sido passados para as escolas que os receberam. Consideram que "há falha até de não avisar (a escola?) que os alunos vieram de classes de aceleração." Embora um outro professor considere que não ter essa informação até "pode evitar discriminação, mesmo inconsciente".

As falas dos professores permitem ampliar a compreensão dos sucessos e dificuldades dos egressos de classes de aceleração. Assim, dizem: "Há alunos que não são egressos e que também têm muita dificuldade. $\bigcirc$ trabalho feito na classe de aceleração deveria ser com todas." Depreende-se de suas falas que alunos egressos e não egressos, aos seus olhos, têm muitas dificuldades, algumas semelhantes, outras diferentes; mas, ao final do trabalho, obtémse resultados semelhantes quanto ao conteúdo aprendido.

Um fato importante se destaca na organização dos egressos nas escolas: em várias delas, os egressos foram colocados em uma mesma classe, separados dos demais alunos. Essa forma da organização dá origem a uma rejeição da classe pelos professores: "São muito fracos. Fica muito difícil trabalhar com eles". Em uma escola, a direção juntou os alunos egressos em uma só sala, em um ano, o que gerou protestos por parte dos professores. Para 1999, a direção não sabia ainda se iria separá-los... Em outra escola, a professora revela ter ficado muito assustada com a classe só de egressos; não se sentia preparada e relatava que alguns alunos não estavam nem alfabetizados; tinham muitas dificuldades:

Não tivemos nenhuma informação para dar continuidade ao trabalho. Agora, estamos fazendo um curso, mas começamos em junho. $\bigcirc$ tempo para fazer um trabalho diferen- 
ciado é curto, pois tenho que dar aulas também em outras classes, a quantidade de alunos por classe é muito grande e a classe dos egressos é diferente. Eles só querem agrado; são complicados - não só para mim, mas para todos os professores. E eles não correspondem à atenção que recebem: sempre querem mais e não conseguimos dar.

A queixa de que as classes são numerosas e de que isso dificulta o acompanhamento dos alunos - egressos ou não - é bastante freqüente.

O fato de os professores reclamarem de que os alunos solicitam - exigem mesmo maior atenção ("Eles não correspondem à atenção que recebem. Sempre querem mais e não conseguimos dar"), parece nos dizer da dificuldade do professor de se envolver no processo ensino-aprendizagem, de identificar mais claramente seu papel de educador, seu compromisso com os alunos.

Um ponto que se destaca é a dificuldade de trabalho integrado. Os professores referem-se à falta de integração do trabalho na unidade escolar em dois sentidos: falta de integração entre os professores e falta de integração entre as atividades (por exemplo, entre as atividades da aula diária e as da aula de reforço).

Percebe-se, também, a falta de um processo de discussão sobre os alunos egressos, suas dificuldades e possibilidades, sobre o projeto pedagógico da escola e os compromissos desta e dos professores em relação aos alunos e à educação.

Alguns professores assimilaram condutas enfatizadas na classe de aceleração - e em outros projetos da SEE/SP - acompanhando o progresso dos alunos pela sua produção cotidiana. Muitos não se utilizam de instrumentos formalizados - provas - ou de dias especificamente determinados para a avaliação. E essa forma de avaliar lhes parece permitir uma visão mais próxima e contextualizada dos alunos e sua aprendizagem. Esse tipo de acompanhamento é realizado pela professora de Português cujos alunos egressos tiveram o melhor desempenho.

O que se conclui das entrevistas e das observações realizadas pelos pesquisadores é a necessidade do preparo dos professores de alunos egressos para recebê-los e acompanhá-los, com informações mais sistematizadas e completas sobre o Projeto Classes de Aceleração, para que haja continuidade no processo de aprendizagem desses alunos. É uma constante na fala dos professores a necessidade de orientação para trabalhar com o aluno defasado. Falam em cursos, capacitação, material especial, revelando seu incômodo em não dar conta do recado.

A maioria dos professores aponta a dificuldade de trabalhar não só com o egresso, mas com classes heterogêneas. $\bigcirc$ não saber trabalhar com grupos heterogêneos é desgastante para o professor e reafirma a necessidade de uma preocupação com sua formação contínua.

A fala dos professores aponta também para limites da escola, para problemas que fogem ao seu alcance, como o aluno trabalhador e o aluno vítima da violência. Essas questões devem ser enfrentadas por medidas que vão além do trabalho escolar, pois se ligam a questões econômicas, sociais, familiares, que só poderão ser enfrentadas por políticas sociais mais amplas. 
Com alguns ajustes nas políticas educacionais, grandes resultados poderão ser obtidos, corrigindo-se algumas distorções ora identificadas. $\bigcirc$ aluno egresso não parece fadado ao insucesso, tanto é que, em muitas escolas, em que pese o baixo desempenho geral, obtiveram melhor ou igual resultado em comparação com os não egressos.

\section{CONSIDERAÇÕES FINAIS}

O Projeto das Classes de Aceleração, como ação pontual da Secretaria da Educação, no sentido de uma política de inclusão e não de exclusão, teve êxito. As escolas se organizaram e atuaram política e pedagogicamente para que o aluno não as abandonasse.

Os resultados dos estudos de caso evidenciam que o sucesso do Projeto das Classes de Aceleração está associado à existência de um projeto político-pedagógico fundamentado em achados da pesquisa educacional. Dele decorre um desenho organizacional que inclui: classes menores, com material didático pertinente aos conteúdos e aos alunos realmente presentes naquela sala de aula; profissionais experientes, dispostos a estudar e a aprender, acompanhados, em seu trabalho pedagógico, por ações capacitadoras competentes. Esse arranjo possibilita que a aprendizagem se efetive e que professores e alunos se sintam, na escola, mais realizados e comprometidos.

Ficou também evidente, pelos depoimentos e observações realizadas durante os estudos de caso que essas condições deveriam se estender a toda a rede de ensino. Isso não significa estender o programa das classes de aceleração para toda a rede. Significa, sim, dar às escolas as mesmas condições: recursos, material, capacitação, número razoável de alunos por classe.

Essa constatação se reafirma na análise dos resultados do estudo dos egressos. Nas entrevistas, os professores revelam suas dificuldades para atender a classes numerosas e heterogêneas, em termos de nível de aprendizagem e de dificuldades escolares, sociais e emocionais. Não se sentem pedagogicamente preparados para realizar um trabalho de recuperação desses alunos e se ressentem da falta de suporte por parte das escolas e das demais instâncias do sistema. Por outro lado, afirmam não ter informações suficientes sobre a proposta das classes de aceleração e sobre os egressos, e dizem não saber onde buscar recursos para seu atendimento.

Revelam também os professores sua insatisfação pela freqüência irregular dos egressos. Tanto pela fala dos docentes como pelas observações feitas nas escolas, constata-se um problema de assiduidade dos egressos, que, em algumas escolas, parece não estar sendo devidamente controlado, deixando dúvidas sobre o que efetivamente ocorre com os alunos ausentes: estão cursando o noturno, o supletivo ou abandonaram a escola? Estarão passando por dificuldades econômicas ou pessoais que os impedem de freqüentar a escola?

É preciso considerar os limites da escola para atender a todas as necessidades dos alunos, em razão dos diversos agravos sociais e familiares que sofrem, e a dificuldade de 
estabelecer políticas sociais que possam contemplar todos esses agravos. Além disso, há de se levar em conta que, em apenas um ano, seria muito difícil superar deficiências que vieram se acumulando ao longo de anos e que, além disso, extrapolam o âmbito escolar. Esse estudo mostra que os alunos das classes de aceleração têm dificuldades de várias ordens. As ações realizadas na escola jamais poderiam abarcar todas elas. Por isso mesmo, um projeto desse porte deveria incluir também medidas de médio e longo prazo, que ajudassem a manter as transformações e os resultados positivos alcançados.

As observações feitas pelos pesquisadores mostram que, quando há uma presença atuante e comprometida do diretor e do coordenador pedagógico, há maior conhecimento do projeto e envolvimento de professores com o trabalho pedagógico e com os próprios alunos, o que se reflete em resultados escolares melhores.

Os dados do estudo dos egressos vêm comprovar que, do ponto de vista do desempenho do aluno, os egressos tiveram notas similares às dos seus colegas de $4^{a}$ e $5^{\text {a }}$ séries, nas provas de Português e Matemática.

Considerando que esses alunos, com grandes atrasos na escolaridade e uma história marcada pelo fracasso, tiveram apenas um ano para desenvolver habilidades requeridas pela escola, a partir do projeto, os resultados obtidos na continuidade dos seus estudos, mesmo sendo baixos, ganham importância. Há de se considerar que o desempenho dos alunos não egressos também foi baixo, o que, mais uma vez, confirma a importância de implementar melhores condições de trabalho para toda a rede.

Nos resultados do Inventário de Auto-Estima foi observado que os egressos apresentam índices mais elevados de baixa auto-estima (auto-estima negativa) do que os não egressos, isto é, essa auto-estima negativa é mais fortemente evidenciada entre os egressos. Podese levantar a hipótese de que os egressos que tiveram, nas classes de aceleração, a oportunidade de um trabalho sistemático com relação à auto- estima, se ressentem mais, nas classes regulares, da ausência de atenção especial. A formação do professor, para lidar com este aspecto e outros presentes na relação pedagógica, pode ser considerada um dos fatores de forte peso nos resultados apresentados.

Ao longo deste estudo, muitas ações positivas do Projeto das Classes de Aceleração ficaram evidentes. Ao mesmo tempo, distorções e falhas também emergiram dos dados. Neste sentido, cabe ressaltar a importância de processos de acompanhamento e avaliação interna e externa de projetos dessa natureza, para identificação e reafirmação dos aspectos positivos e correção dos que necessitam ser reformulados.

\section{REFERÊNCIAS BIBLIOGRÁFICAS}

FUNDAÇÃO CARLOS CHAGAS. Núcleo de Avaliação Educacional. Inventário de autoestima. São Paulo, 1997. 
- Relatório de avaliação final do Programa de Aceleração da Aprendizagem. São Paulo, 1998.

IDÉIAS. São Paulo: FDE, n.28, 1997.

INSTRUCTIONAL OBJECTIVES EXCHANGE. Measures self conceptk- /2. Revised Edition. California, 1972.

PERRAUDEAU, M. Les Cycles et la différenciation pédagogique. Paris: Armand Colin, 1997. PERRENOUD, P. La Pédagogie à l'école des differences. Paris: ESF, 1996. . Pédagogie differenciée: des intentions à l'action. Paris, ESF, 1997.

SACRISTÁN, J. G. Autoconcepto, sociabilidad y rendimiento escolar. Madrid: Departamento de Prospección Educativa, 1976.

SÃO PAULO (Estado) Secretaria da Educação. Ensinar pra valer! Aprender pra valer!: avaliação. FDE, 1998a. . Ensinar pra valer! Aprender pra valer!: classes de aceleração. FDE, 1998.

- Reorganização da trajetória escolar no ensino fundamental: classes de aceleração; proposta pedagógica curricular e demais documentos. FDE, 1997. 
